\title{
Hydrogen bioproduction with Enterobacter sp. isolated from brewery wastewater
}

\author{
Sandra Imaculada Maintinguer ${ }^{a, b, *}$, Carolina Zampol Lazaro ${ }^{c}$, \\ Renan Pachiega ${ }^{d}$, Maria Bernadete Amâncio Varesche ${ }^{e}$, Rodrigo Sequinel ${ }^{f}$, \\ José Eduardo de Oliveira ${ }^{d}$ \\ a IPBEN - Bioenergy Institute, UNESP, 13550-230, Rio Claro, SP, Brazil \\ ${ }^{\mathrm{b}}$ UNIARA - University of Araraquara, 14801-320, Araraquara, SP, Brazil \\ C Département Microbiologie, Infectologie et Immunologie, Université de Montréal, Montreal, Canada \\ ${ }^{\mathrm{d}}$ CEMPEQC - Center for Monitoring and Research of the Quality of Fuels, Biofuels, Crude Oil, and Derivatives, \\ Institute of Chemistry, UNESP, 14801-970, Araraquara, SP, Brazil \\ e USP - University of Sao Paulo, 13563-120, Sao Carlos, SP, Brazil \\ ${ }^{\mathrm{f}}$ Laboratory of Catalysis Biofuel Production, Federal University Paraná, 85950-000, Palotina, PR, Brazil
}

\section{A R T I C L E I N F O}

Article history:

Received 14 June 2016

Received in revised form

13 November 2016

Accepted 14 November 2016

Available online 12 January 2017

\section{Keywords:}

Bio $\mathrm{H}_{2}$

Roll tubes

Dark fermentation

Enterobacter sp.

Mesophilic conditions

Brewery wastewater

\begin{abstract}
A B S T R A C T
Hydrogen-producing bacterial strains were isolated from granular sludge from a UASB reactor that treats brewery wastewater. Most of the isolated strains were related to the Enterobacter genus through a phylogenetic analysis of the 16S rRNA sequences. The strains could use various carbon sources (sugars and glycerol) to produce hydrogen. The isolated strain, identified as Enterobacter sp. based on 16S rRNA gene sequencing, produced $6.8 \mathrm{mmol} \mathrm{H}_{2} \mathrm{~L}^{-1}$ culture medium when growing on glucose $\left(2.0 \mathrm{~g} \mathrm{~L}^{-1}\right)$ in anaerobic conditions at $30{ }^{\circ} \mathrm{C}$. The main liquid metabolites were acetic acid $\left(367 \mathrm{mg} \mathrm{L}^{-1}\right.$ ), methanol (437 $\mathrm{mg} \mathrm{L}^{-1}$ ) and ethanol (1101.26 $\mathrm{mg} \mathrm{L}^{-1}$ ), after $9 \mathrm{~h}$ of fermentation. The maximum hydrogen yield of $0.8 \mathrm{~mol} \mathrm{H}_{2} / \mathrm{mol}$ glucose was observed, indicating that Enterobacter sp. isolated from brewery wastewater was an efficient hydrogen-producing bacterium under mesophilic conditions.
\end{abstract}

๑ 2016 Hydrogen Energy Publications LLC. Published by Elsevier Ltd. All rights reserved.

\section{Introduction}

A limited source of fossil fuels and environmental issues related to their combustions has driven to intensive searches for alternative energy sources worldwide. The hydrogen has been considered a potential energy carrier for the future and its production has been the focus of several researches. It can be produced through physicochemical and biological processes. One of the advantages of the biological hydrogen production is that it can occur under room pressure and temperature, and there is also the possibility of using several organic wastes as a substrate for microbial growth and biogas production [1].

Agricultural and industrial wastewaters are rich in organic matters as well as in nutrient compounds, which can benefit the bacterial growth. Therefore, the use of those wastes for

\footnotetext{
* Corresponding author. IPBEN - Bioenergy Institute, UNESP, 13550-230, Rio Claro, SP, Brazil.

E-mail address: mainting2008@gmail.com (S.I. Maintinguer). 
bacterial fermentation for hydrogen production allows the production of clean renewable sources of energy and wastewater treatment, minimizing the cost of both processes [2].

Beer is one of the most consumed beverages around the world, losing only to tea, milk and coffee [3]. The brewing industry generates large amounts of highly polluting effluents (3-10 L of effluents for each liter of beer). Their compositions are variable upon to the process step (e.g. brewing and packing). For example, the effluents generated from bottle washing steps are produced in large amount; however, their organic matter concentration is lower than the brewing and filtering steps effluents, which have high BOD (Biochemical Oxygen Demand) content [4]. The global beer production from 2004 to 2014 increased about 37.26 million kiloliters. China presented the highest growth in beer production volume, followed by Brazil (about 5.42 million kiloliters) and Vietnam [5].

The conventional methods of treating brewery wastewater include physical, chemical and biological processes. The last one is based on the activity of a wide range of microorganisms, either through aerobic or anaerobic processes. Its advantages over physicochemical or chemical methods rely mainly on its high efficiency of COD (Chemical Oxygen Demand) and BOD removal and low investment cost [6].

Many studies have been developed worldwide in the past two decades with the aim of increasing hydrogen production rates and yields. Furthermore, their focus is also to look for potential solid wastes and wastewaters [7-9], which are considered ideal substrates at the economic point of view. Consortia of microorganisms from industrial sludges include anaerobic and facultative bacteria and they would be used for hydrogen production [10]. Additionally, their aim is to screen and isolate new hydrogen producing bacterial strains from natural (soil, compost, plant, animal) and artificial sources (industrial treatment plants sludge) $[11,12]$ under mesophilic conditions [13]. Among the mesophilic anaerobes, Clostridium species have been isolated and used for several authors [14-16]. In bioreactors operated at thermophilic temperatures, Thermoanaerobacterium species have been often employed as an inoculum source [17-19]. Besides anaerobes, facultative microorganisms, such as Enterobacter species, can produce hydrogen by themselves $[11,12,20,21]$ and also play an important role in co-cultures for dark fermentative hydrogen production bioreactors, by consuming oxygen and making the environment anaerobic for the strict anaerobes [22,23]. It is worth to highlight that just only few studies have been investigating the biological hydrogen production through the facultative anaerobic bacteria, such as Enterobacter species. These pure cultures have been tested during fermentative processes of hydrogen production with crude glycerol [24]. Strains as Enterobacter aerogenes HGN-2 and HT 34, isolated from sea crude oil pipelines, demonstrated the ability to produce hydrogen yielding almost $2 \mathrm{~mol} \mathrm{H}_{2} / \mathrm{mol}$ xylose [23]. In order to improve the hydrogen yields, Box-Behnken experimental design evaluated the performance of a newly isolated Enterobacter $\mathrm{CN} 1$ that yielded 0.6 and $2 \mathrm{~mol} \mathrm{H}_{2}$ per mol of glucose and xylose, respectively [25]. Based on a Plackett-Burman design there were identified important parameters (glucose, initial $\mathrm{pH}$ and ferric chloride) that affected the hydrogen production by E. aerogenes (MTCC 111). The maximum yield of $1.7 \mathrm{~mol} \mathrm{H}_{2} / \mathrm{mol}$ glucose was achieved using statistical design [26]. . Recently, it was demonstrated that at a certain degree the hydrogen producing Enterobacter cloacae augmented biogas production in anaerobic digesters [27].

Therefore, the bioaugmentation or a defined co-culture (facultative and anaerobic) can be interesting alternatives to improve several industrial biotechnological processes and, recently, it has been applied for biological hydrogen production as well $[28,29]$. Thus, the aim of this study was to isolate several hydrogen producing facultative bacterial strains from brewery wastewater treatment plant sludge and characterize them phylogenetically through 16S rRNA gene fragments analysis. Furthermore, it aimed to screen for potential high yield facultative strains able to grow and produce hydrogen from different carbon sources (dextrose, maltose, xylose, glucose, sucrose, fructose, lactose, starch, and glycerol), which may be present in several wastewaters.

\section{Material and methods}

\section{Inoculum source and culture conditions}

The inoculum was a granular sludge from the Upflow Anaerobic Sludge Blanket (UASB) reactor treating brewery wastewater (Araraquara - Brazil). The PYG culture media used in the experiments were prepared by the dissolution of $10 \mathrm{~g} \mathrm{~L}^{-1}$ the carbon source (glucose or dextrose, maltose, xylose, sucrose, glycerol, fructose, lactose, starch, all of them were added separately), peptone $\left(5 \mathrm{~g} \mathrm{~L}^{-1}\right)$, yeast extract $\left(5 \mathrm{~g} \mathrm{~L}^{-1}\right)$, and meat extract $\left(5 \mathrm{~g} \mathrm{~L}^{-1}\right)$ in distilled water, prepared under anaerobic conditions, by the flush of $\mathrm{N}_{2}$. After the preparation, the culture media were sterilized (at $121^{\circ} \mathrm{C}$ for $20 \mathrm{~min}$ ). All the experiments were carried out in a temperature controlled incubator (BOD -246/364 220V-SOLAB), kept at $37^{\circ} \mathrm{C}$.

\section{Enrichment phase, isolation of the bacterial strains and nutritional characterization}

The inoculum was transferred to a mortar with pestle in order to undo the granular arrangement and then it was submitted to the heat treatment $\left(90^{\circ} \mathrm{C}\right.$, for $\left.15 \mathrm{~min}\right)$, in order to inactivate the hydrogen consumers [30]. Afterward, this biomass was cultured in PYG medium (glucose, $10 \mathrm{~g} \mathrm{~L}^{-1}$; peptone, $5 \mathrm{~g} \mathrm{~L}^{-1}$; yeast extract, $5 \mathrm{~g} \mathrm{~L}^{-1}$, and meat extract, $5 \mathrm{~g} \mathrm{~L}^{-1}$ ) at $37^{\circ} \mathrm{C}$, with initial $\mathrm{pH} 5.5$, during $96 \mathrm{~h}$. The samples from the headspace of the flasks were then analyzed and a hydrogen production was detected. Thus, the biomass was submitted to serial dilutions with PYG media and initial $\mathrm{pH}$ 5.5 , in order to obtain the enrichment and selection of the hydrogen producing microorganisms.

The enriched culture was grown in PYG medium during 15 days and it was used as inoculum for the isolation phase. The isolation of the strains was performed in roll tubes using the same culture medium solidified with agar (2\%). After the growth, single colonies were selected and picked up with strap platinum needle, and suspended in $100 \mu \mathrm{L}$ of PYG medium, under aseptic conditions in a sterile tube $(1 \mathrm{~mL})$. The cellular suspension was then inoculated into serum vials $(20 \mathrm{~mL})$ containing PYG medium $(10 \mathrm{~mL})$. The vials were incubated for approximately 10 days at $37^{\circ} \mathrm{C}$ without agitation. This process 
was carried out with 30 colonies. The vials were incubated until the microbial growth. The hydrogen production was measured through gas chromatographic analysis from headspace samples, and the cell growth was quantified by the turbidity of medium $\left(\mathrm{OD}_{600}\right)$. In the vials in which hydrogen production was detected, the cells were reactivated in the PYG medium and samples were taken to microscopic and 16S rRNA gene sequencing analysis.

After the isolation phase, a nutritional requirement screening for hydrogen generation was performed. The tests were performed in serum vials $(20 \mathrm{~mL})$ in duplicate, using as inoculum $20 \%(\mathrm{v} / \mathrm{v})$ of each isolated strain after the reactivation step. The following carbon sources $\left(10 \mathrm{~g} \mathrm{~L}^{-1}\right)$ were used as substrates: glucose or fructose, sucrose, xylose, starch, glycerol, dextrose, maltose, and lactose. The vials were incubated, as described previously, during 10 days. After this period, the hydrogen production was quantified (gas chromatography), as well as the cell growth $\left(\mathrm{OD}_{600}\right)$. Microscopic analyses were performed in order to visualize the morphologies of the isolated strains.

\section{Kinetic tests of hydrogen production, substrate consumption and fermentation products}

One of the isolated strains, identified as Enterobacter sp. (accession number KP893397 from NCBI database), was submitted to successive washes in a refrigerated centrifuge at $8500 \mathrm{rpm}$ and $4{ }^{\circ} \mathrm{C}$ for $10 \mathrm{~min}$. The pellet was re-suspended in a fresh PYG modified medium (glucose, $2 \mathrm{~g} \mathrm{~L}^{-1}$; peptone, $5 \mathrm{~g} \mathrm{~L}^{-1}$; yeast extract, $5 \mathrm{~g} \mathrm{~L}^{-1}$, and meat extract, $5 \mathrm{~g} \mathrm{~L}^{-1}$ ), and incubated at $37{ }^{\circ} \mathrm{C}, \mathrm{pH} 7.0$, during $24 \mathrm{~h}$. After that, $20 \%$ (v/v) of the reactivated biomass were used as seed inoculum for hydrogen production tests. The reactors were prepared in triplicate in Duran ${ }^{\circledR}$ flasks with a total volume of $2 \mathrm{~L}$ and working volume of $1 \mathrm{~L}$ (PYG modified, described previously), capped with butyl rubber stoppers. The reactors were kept at $37{ }^{\circ} \mathrm{C}$, without agitation, during approximately $50 \mathrm{~h}$. In these experiments, it was able to quantify the hydrogen production, substrate consumption and fermentation products generated.

\section{Chemical and chromatographic analysis}

Hydrogen, methane and carbon dioxide contents in the biogas were determined simultaneously in a single gas chromatography run in a TOGA (Transformer Oil Gas Analyser system) [31], coupled with a Trace GC Ultra - Thermo Gas Chromatograph, equipped with split/splitless injectors and two detectors: thermal conductivity detector (TCD), and flame ionization detector (FID) with methanizer. The fraction containing Hydrogen, Nitrogen and Methane was analyzed by an Rt-MSieve $5 \mathrm{~A}^{\circ} 30 \mathrm{~m} \times 0.53 \mathrm{~mm}$ i.d. column. Hydrogen and Nitrogen were detected by the TCD. Methane was detected by the FID, after passing through the methanizer. When the molecular sieve column was by-passed, Carbon dioxide was eluted from the porous polymer Carboxen 1006 plot $30 \mathrm{~m} \times 0,53 \mathrm{~mm}$ i.d column and detected by the flame ionization detector (FID), after passing through the methanizer. Argon was used as carrier gas $\left(1.5 \mathrm{~mL} \mathrm{~min}^{-1}\right.$ in splitless mode). The temperature of the FID detector was $250^{\circ} \mathrm{C}$; the TCD detector and injector were adjusted to $150{ }^{\circ} \mathrm{C}$. The oven programming was $50{ }^{\circ} \mathrm{C}$ (4.5 min), heating $40{ }^{\circ} \mathrm{C} \mathrm{min}^{-1}$ to $180{ }^{\circ} \mathrm{C}(1.5 \mathrm{~min})$ and then cooling $50{ }^{\circ} \mathrm{C} \mathrm{min}-1$ to $50{ }^{\circ} \mathrm{C}$ (3.15 $\mathrm{min}$ ). The production of $\mathrm{H}_{2}$ was calculated considering the atmospheric pressure, and expressed as $\mathrm{mmol} \mathrm{H}_{2} \mathrm{~L}^{-1}$.

Volatile fatty acid and alcohol concentrations were measured by gas chromatography using a GC 2010 (Shimatzu $\left.^{\circledR}\right)$, equipped with a flame ionization detector and a sample introduction system to COMBI-PAL headspace (AOC 5000 model and HP-INNOWAX column of $30 \mathrm{~m} \times 0.25 \mathrm{~mm} \mathrm{x}$ $0.25 \mu \mathrm{m}$ of film thickness) [32].

The glucose concentration was determined through a colorimetric method [33,34]. The $\mathrm{pH}$ values and cellular growth were performed, based on the optical density at $600 \mathrm{~nm}(\mathrm{OD} 600)$ [35].

\section{Microbiological analysis}

DNA extraction, amplification and 16S rRNA gene fragment analysis Nucleic acid extractions were performed [36], into a direct method with glass beads and a mixture of phenol: chloroform: buffer (1:1:1 v/v) addition. A segment of the $16 \mathrm{~S}$ rRNA gene was amplified through PCR, using the set of primers 27 forward (5'AGA GTT TGA TCM TGG CTC AG-3') and 1110 reverse (5'-GGG TTG CGC TCG TTG-3') [37]. The unpurified PCR products were sent to Macrogen Inc ${ }^{\circledR}$ [38] for nucleotide sequence analysis. A comparative analysis was performed using the Ribosomal Database Project (RDP) [39] and the Basic Local Alignment Search Tool (BLAST) [40] was used to search the National Center for Biotechnology Information sequence database [41]. The phylogenetic tree was developed using the software RDP-Tree Builder Version 10.0 (Neighbor treeing program). Bootstrap analyses for 1000 replicates were performed to estimate the confidence of the tree topologies. The confidence threshold adopted was $99 \%$ for the specie taxonomic level and $88 \%$ for the genus taxonomic level.

\section{Accession numbers of the sequences}

The sequences of the isolates determined in this work were deposited in the NCBI database under the following accession numbers: KP893391, KP893392, KP893393, KP893394, KP893395, KP893396, KP893397, KP893398, KP893399, KP893400, KP893401, KP893402, KP893403 (strains from 1 to 13, respectively).

\section{Experimental data fitting}

The mean values of each anaerobic batch reactor were adjusted using Statitica ${ }^{\circledR}$ software, version 8.0, according to Equation (1). The maximum rate of hydrogen production was obtained through a non-linear sigmoidal adjust of modified Gompertz function [42].

$H=P \cdot \exp \left\{-\exp \left[\frac{R m \cdot e}{P}(\lambda-t)+1\right]\right\}$

where $P$ is the hydrogen production potential $\left(\mathrm{mmol} \mathrm{H}_{2} \mathrm{~L}^{-1}\right.$ of culture medium), $\mathrm{Rm}$ is the maximum hydrogen production rate ( $\mathrm{mmol} \mathrm{H}_{2} \mathrm{~L}$ of culture medium $\mathrm{h}^{-1}$ ), $\lambda$ is the lag phase (h) of $\mathrm{H}_{2}$ generation and $e$ is equals to 2.718281828 . 


\section{Results and discussion}

The first part of the present study was a screening for hydrogen producing bacterial strains that were isolated from sludge from the brewery wastewater treatment plant. Among the 30 isolated strains, it was possible to observe $\mathrm{H}_{2}$ generation from 13 strains. They were identified as Enterobacter Genus (strains 1-4 and 6-13) and uncultured bacterium from Propionicum Genus (strain 5) (Table 1). Rods, that are characteristic of the Enterobacter species, composed the observed morphology (data not shown). The most known fermentative hydrogen bacteria include species of Enterobacter, Bacillus and Clostridium species $[43,44]$.

Four isolates (1, 2, 3, and 4) presented high homology 99\% to Enterobacter ludwigii, a Gram-negative bacterium, belonging to the Enterobacter Genus (Fig. 1). Zhang et al. [46] identified E. ludwigii in DGGE analysis of the anaerobic granular sludge collected from an expanded granular sludge bed reactor (EGSB) that treated starch wastewater for biological hydrogen production with corn stover hydrolyzate. Therefore, E. ludwigii is probably involved in fermentation processes of hydrogen generation.

Eight isolates $(6,7,8,9,10,11,12$, and 13) were related to Enterobacter sp. (Fig. 1). Subudhi et al. [47] operated anaerobic batch reactors with pure cultures of E. cloacae, $\mathrm{pH} 7.0$, at $37^{\circ} \mathrm{C}$; fed with xylose, glycerol, and cellulose. The authors ([47]) obtained maximum generation of $\mathrm{H}_{2} 27 \mathrm{mmol} \mathrm{L}^{-1}$. Kumar \& Das [20] operated anaerobic batch reactors inoculated with $E$. cloacae and obtained $6 \mathrm{~mol} \mathrm{H} / \mathrm{mol}$ of sucrose at $36^{\circ} \mathrm{C}$ and $\mathrm{pH}$ 6.0. E. cloacae also produced $\mathrm{H}_{2}$ with cellobiose $\left(5.4 \mathrm{~mol} \mathrm{H}_{2} / \mathrm{mol}\right.$ of cellobiose).

One strain (number 5) showed high similarity to uncultured bacterium belonging to the Propionicum Genus (Fig. 1), which comprises Gram-positive rod-shaped cells capable of propionic acid generation. It is mostly likely that Enterobacter and Propionibacterium were growing jointly in the brewery sludge because of their metabolic capabilities. It can be suggested that Enterobacter was fermenting sugars and releasing lactate in the medium that was later fermented by Propionibacterium. The majority of the isolated strains closely related to Enterobacter sp. could reflect its predominance in the composition of the sludge. Ren et al. [48] assessed the relationship between the predominance of certain bacterial species in a mixed culture and the fermentation type. The authors ([48]) found out that butyric acid and propionic acid fermentations types were dominated by Clostridium sp. and Propionibacterium sp., respectively. In another study, the large amount of Propionibacterium was observed after acid inoculum pretreatment [49].

Fig. 1 presents the consensus phylogenetic tree obtained with primers for Bacteria Domain from the isolates' cultures.

There were obtained hydrogen production on all carbon sources tested. The maximum cumulative hydrogen productions were (mmol $\mathrm{H}_{2} \mathrm{~L}^{-1}$ ) 8.03; 10.68; 11.22; 8.38; 14.36; 10.90; 7.09; 5.41 and 9.89 for dextrose, maltose, xylose, dextrose, glycerol, fructose, starch, lactose and glucose, respectively by different isolated strains (Table 2). During the tests, the higher hydrogen productions were observed using isolates strains with glycerol, xylose and fructose, as showed below. Subudhi et al. [47] applied heat treatment on a crude oil source with the aim of inactivating methanogenic microorganisms. The authors isolated E. cloacae DT-1 and used it during the operation of anaerobic batch reactors, with initial $\mathrm{pH} 7.0$ at $37{ }^{\circ} \mathrm{C}$, and different carbon sources at $10 \mathrm{~g} \mathrm{~L}^{-1}$, including glycerol. They obtained lower values of hydrogen generation $\left(6.6 \mathrm{mmol} \mathrm{H}_{2} \mathrm{~L}^{-1}\right)$ than our results $(14.4 \mathrm{mmol}$ $\mathrm{H}_{2} \mathrm{~L}^{-1}$ ). Long et al. [25] obtained generation of $\mathrm{H}_{2}$ with glucose, xylose, and sucrose as well as this study. However, it was observed higher results in anaerobic reactors fed with xylose (14.15 g of xylose $\mathrm{L}^{-1}$, at $40^{\circ} \mathrm{C} \mathrm{pH} \mathrm{7.0)} \mathrm{than} \mathrm{those} \mathrm{supplemented}$ with glucose and sucrose.

As commented previously, one of the isolated strains was used for kinetic tests Enterobacter sp. (KP893397), in which hydrogen production, substrate consumption and fermentation products were measured. The maximum cumulative hydrogen production was $6.8 \mathrm{mmol} \mathrm{H}_{2} \mathrm{~L}^{-1}$ achieved in $8.8 \mathrm{~h}$ of

\section{Table 1 - Phylogenetic affiliation of the isolated bacterial strains.}

\begin{tabular}{|c|c|c|c|c|c|}
\hline Isolated strains & Closest species in Genbank & Accession number & Similarity (\%) & Base pairs & Reference \\
\hline $1-4$ & Enterobacter ludwigii & FR820478.2 & 99 & 1112 & Unpublished \\
\hline 5 & Uncultered bacterium clone & JF200891.1 & 99 & 1098 & [45] \\
\hline $6-13$ & Enterobacter sp. KK1 & GQ871449.1 & 99 & 1121 & Unpublished \\
\hline
\end{tabular}

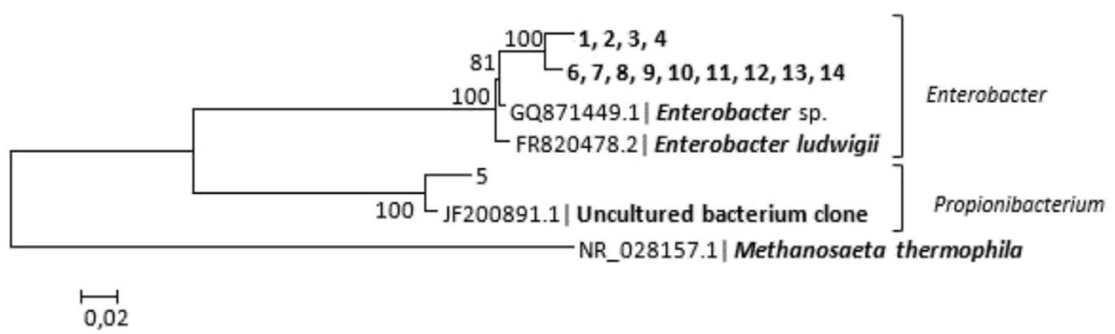

Fig. 1 - Consensus phylogenetic tree based on sequences of isolated strains. The bootstraps values indicate the repetition percentages (1000 replicate runs). Methanosaeta thermophile (NR 028157.1) was added as an out-group. 
Table 2 - Nutritional characterization and generation of $\mathrm{H}_{2}\left(\mathrm{mmol} \mathrm{L}^{-1}\right)$ with isolated strains.

\begin{tabular}{|c|c|c|c|c|c|c|c|c|c|}
\hline Isolated strain & Dextrose & Maltose & Xylose & Sucrose & Glycerol & Fructose & Starch & Lactose & Glucose \\
\hline 1 & 4.96 & 10.68 & 11.22 & 6.85 & 5.45 & 9.23 & 4.37 & 4.50 & 9.20 \\
\hline 2 & 5.81 & 9.79 & 11.01 & 7.78 & 5.35 & 7.05 & 4.52 & 4.37 & 7.12 \\
\hline 3 & 8.03 & 7.46 & 8.04 & - & 6.69 & 7.56 & 3.41 & 5.41 & 7.10 \\
\hline 4 & 6.21 & 6.79 & 6.51 & 8.38 & 4.49 & 10.90 & 3.36 & 2.92 & 9.89 \\
\hline 5 & 5.41 & 8.17 & 8.18 & 4.15 & 6.70 & 6.91 & 5.20 & 4.60 & 6.80 \\
\hline 6 & 5.41 & 4.89 & 6.01 & 5.16 & 3.45 & 5.33 & - & 3.54 & 5.45 \\
\hline 7 & 6.87 & 14.66 & 5.22 & 4.81 & 2.54 & 7.76 & 2.13 & 3.13 & 7.89 \\
\hline 8 & 5.11 & 5.10 & 2.89 & 6.56 & 4.48 & 2.44 & 1.68 & - & 3.90 \\
\hline 9 & 6.79 & - & 5.51 & - & - & - & - & - & - \\
\hline 10 & 6.03 & 4.58 & 1.16 & 5.09 & 3.57 & 4.32 & 2.21 & 5.41 & 4.12 \\
\hline 11 & 3.05 & 5.37 & 4.35 & 4.89 & 14.36 & 4.93 & 2.84 & 2.04 & 4.56 \\
\hline 12 & 6.01 & 4.65 & 4.95 & 7.31 & 4.28 & 4.84 & 2.16 & 1.81 & 4.69 \\
\hline 13 & 4.52 & 7.03 & 3.66 & 3.86 & 7.52 & 6.66 & 7.09 & 2.06 & 6.78 \\
\hline
\end{tabular}

fermentation in anaerobic reactors fed with glucose $\left(2 \mathrm{~g} \mathrm{~L}^{-1}\right)$. These values were higher than the ones obtained by Lazaro et al. [8]. The authors ([8]) operated anaerobic batch reactors fed with vinasse from ethanol production (2 and $5 \mathrm{~g} \mathrm{COD} \mathrm{L}^{-1}$ ) at $55^{\circ} \mathrm{C}$, initial $\mathrm{pH} 5.5$, with sludge from UASB reactor, and they observed a maximum hydrogen generation of 5.0 and $5.2 \mathrm{mmol} \mathrm{H}_{2} \mathrm{~L}^{-1}$, respectively. It should be considered that cumulative hydrogen production is commonly used as unit for data comparison; however, it does not take into account the substrate consumption, which makes difficult the calculation of the real process efficiency.

The consumption of glucose was not complete and at the end of the experiment, it was possible to notice $14.4 \%$ of the initial glucose concentration (Fig. 2). In $3.5 \mathrm{~h}$ of incubation, just $36 \%$ of the initial glucose concentration was degraded by Enterobacter sp. (KP893397). In $8.8 \mathrm{~h}$, when the hydrogen production ceased, the glucose consumption percentage raised to
85.6\%. Similar substrate consumption (84\%) was observed by Maintinguer et al. [30] that evaluated the hydrogen production in anaerobic batch reactor fed with sucrose $\left(1.8 \mathrm{~g} \mathrm{~L}^{-1}\right)$ by a microbial consortium of Clostridium, Enterobacter, and Burkolderia species. Higher substrate consumption (97\%) was obtained in anaerobic reactors fed with xylose $\left(1.8 \mathrm{~g} \mathrm{~L}^{-1}\right)$ [10]. Lower substrate consumption $(37 \%)$ was achieved in anaerobic batch reactors fed with $50 \%$ crude glycerol from cooking oils and $50 \%$ of glycerin at initial concentration of $20 \mathrm{~g} \mathrm{COD} \mathrm{L}^{-1}$ [24]. It is mostly likely that higher substrate consumption are achieved by using simple sugars as substrates, such as glucose and sucrose. However, when residues were applied as carbon source its consumption drops dramatically due to the presence of inhibitory compounds.

Usually, the hydrogen production stops and, sometimes substrate concentration also does, due to the changes in the environmental conditions, such as $\mathrm{pH}$ drop, organic acids

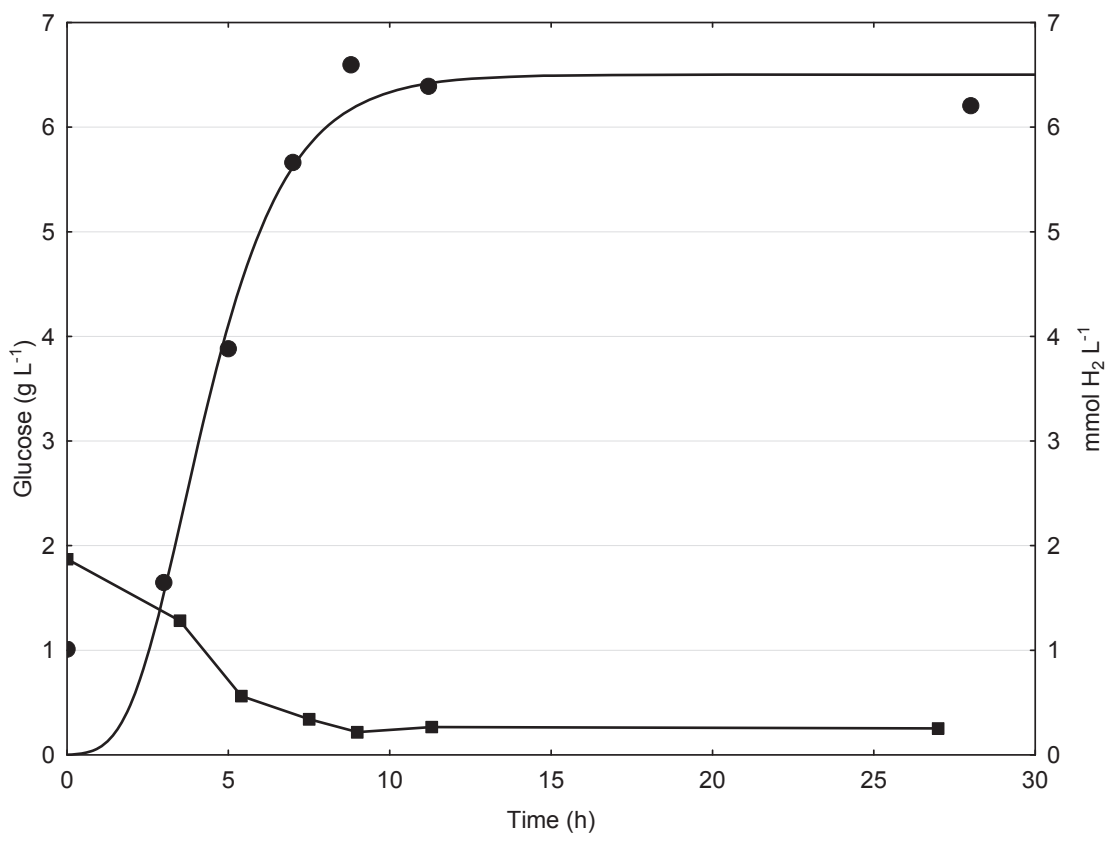

Fig. 2 - Glucose consumption ( $\square$ ) and cumulative hydrogen production $(\bullet)$ during the operation of anaerobic batch reactors inoculated with Enterobacter sp. strain isolated from brewery wastewater. 
accumulation and higher hydrogen partial pressure. The enteric bacteria, such as Enterobacter species, show a mixedacid fermentation. Lactate, ethanol, acetate can be produced beyond $\mathrm{H}_{2}$ and $\mathrm{CO}_{2}$. The metabolic pathway will be driven by the environmental condition, e.g. the lactate production will be favored in acidic conditions. However, the $\mathrm{pH}$ drop, can lead to the decrease in the hydrogen yield due to the metabolic shift. Ethanol can be also produced by enteric bacteria and the hydrogen production will be also affected. An alternative strategy for reducing the negative impact of $\mathrm{pH}$ drop and organic acids accumulation in the hydrogen production is a co-culture of enteric and purple non-sulfur (PNS) bacteria. This approach has been used to increase hydrogen production yield, substrate consumption and COD removal [50].

The hydrogen partial pressure is another environmental condition that has been claimed to affect the hydrogen production [50]. Mandal et al. [51] achieved an increase in the hydrogen yield from $1.9 \mathrm{~mol}$ to $3.9 \mathrm{~mol} \mathrm{H}_{2} \mathrm{~mol}^{-1}$ glucose by decreasing hydrogen partial pressure. Usually, it is done by sparging the headspace of the bioreactor with inert gases. Its main disadvantage relies on the dilution of the hydrogen that has been produced.

The cumulative hydrogen production data obtained in the kinetic test was adjusted to the modified Gompertz model in order to obtain the lag phase and maximum hydrogen production rate. The lag phase of $1.89 \mathrm{~h}$ was observed in the experiments. This value suggests there was not observed any inhibitory effect for the cellular growth and consequent hydrogen production (Fig. 2). Though, the imposed conditions favored the $\mathrm{H}_{2}$ generation in the first hours of the incubation. The estimated hydrogen production potential [(P) $6.5 \mathrm{mmol}$ $\mathrm{H}_{2} \mathrm{~L}$ of culture media ${ }^{-1}$ ] was similar to the one verified in the experiment $\left(6.8 \mathrm{mmol} \mathrm{H}_{2} \mathrm{~L}\right.$ of culture media ${ }^{-1}$ ). Another parameter given by the model adjustment is the maximum hydrogen production rate $(\mathrm{Rm})$. Efforts have been done in order to increase both, the hydrogen yield and maximum hydrogen production rate. It was achieved $1.37 \mathrm{mmol}$ $\mathrm{H}_{2} \mathrm{~L}^{-1} \mathrm{~h}^{-1}$.

The final $\mathrm{pH}$ was 6.1. It was observed the production of organic acids and alcohols. The fermentation of the glucose into organic acid justifies the $\mathrm{pH}$ drop at the end of the experiments. It was observed that organic acids production increased while glucose has been consumed.

Two pathways of glucose degradation can occur in fermentative processes of hydrogen gas production as follows: consumption of glucose generating acetic acid (2) and consumption of glucose generation butyric acid (3).

$$
\mathrm{C}_{6} \mathrm{H}_{12} \mathrm{O}_{6}+2 \mathrm{H}_{2} \mathrm{O} \rightarrow 2 \mathrm{CH}_{3} \mathrm{COOH}+4 \mathrm{H}_{2}+2 \mathrm{CO}_{2}
$$

$\mathrm{C}_{6} \mathrm{H}_{12} \mathrm{O}_{6}+2 \mathrm{H}_{2} \mathrm{O} \rightarrow \mathrm{CH}_{2} \mathrm{CH}_{2} \mathrm{CH}_{2} \mathrm{COOH}+2 \mathrm{H}_{2}+2 \mathrm{CO}_{2}$

There were higher percentages of acetic acid, ethanol and methanol during the operation of the reactors (Fig. 3). The generations of acetic acid (367.0 $\mathrm{mg} \mathrm{L}^{-1}$ ); butyric acid (95.1 $\left.\mathrm{mg} \mathrm{L}^{-1}\right)$; propionic acid $\left(42.3 \mathrm{mg} \mathrm{L}^{-1}\right)$, valeric acid (879.24 $\left.\mathrm{mg} \mathrm{L}^{-1}\right)$, ethanol (1101.26 $\mathrm{mg} \mathrm{L}^{-1}$ ), and methanol (437.01 $\mathrm{mg} \mathrm{L}^{-1}$ ) were observed when there was a higher production of hydrogen (at $8.8 \mathrm{~h}$ of fermentation). Usually, a mixture of acetic, butyric, ethanol and propionic acids is

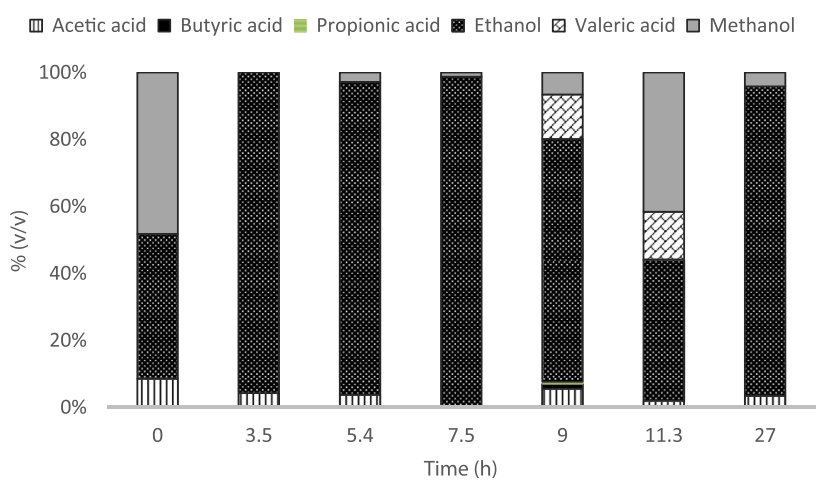

Fig. 3 - Distribution of the main fermentation products observed during the operation of anaerobic batch reactors fed with glucose $\left(2 \mathrm{~g} \mathrm{~L}^{-1}\right)$ inoculated with Enterobacter sp. strain isolated from brewery wastewater.

produced in dark fermentation, depending on the diversity of bacterial species [52]. Higher percentages of acetic and butyric acid favor the hydrogen gas production. However, the generation of propionic acid and alcohols, as ethanol and methanol, consumes $\mathrm{H}_{2}$ when they are produced [53] as observed in this study. Subudhi et al. [47] isolated Enterobacter species from crude oil contaminated soil and they were capable to obtain hydrogen production with glucose and xylose. The main intermediary products generated were acetic acid (528.0 $\mathrm{mg} \mathrm{L}^{-1}$ ) and ethanol (810.0 $\mathrm{mg} \mathrm{L}^{-1}$ ) as well as in the present study. According our results, a mixed-acid fermentation the metabolism of the Enterobacter species was favored to generate the mixtures of organic acids and alcohols occurred. There was observed mainly acetic acid, ethanol, and methanol.

The maximum hydrogen yield from glucose was $0.8 \mathrm{~mol}$ $\mathrm{H}_{2} /$ mol of glucose consumed. These results did not represent $100 \%$ of conversion confirming that the metabolic routes of Enterobacter sp. were not only to acetic and butyric acids generation. It can be seen that hydrogen yields vary significantly among the literature data (Table 3). Nakashimada et al. [54] evaluated the hydrogen production by E. aerogenes HU-101 from different carbon sources and found out a yield of $1.97 \mathrm{mmol} \mathrm{H}_{2} /$ g glucose. Ren et al. [55] assessed the hydrogen production of $E$. aerogenes from monomeric sugars such as xylose, mannose and galactose, and got higher yields (over $2 \mathrm{~mol} \mathrm{H}_{2} / \mathrm{mol}$ substrate). Zhao et al. [56] have gotten similar hydrogen yields by using a wild type E. aerogenes IAM1183 strain and its single and double mutants. Harun et al. [11] observed $1.8 \mathrm{~mol} \mathrm{H}_{2} / \mathrm{mol}$ glucose by E. cloacae. Long et al. [25] observed a hydrogen yield of $0.6 \mathrm{~mol} \mathrm{H}_{2} / \mathrm{mol}$ of glucose when using Enterobacter species isolated from water samples in anaerobic reactors fed with glucose $\left(19.8 \mathrm{~g} \mathrm{~L}^{-1}\right)$ during $33 \mathrm{~h}$ of operation. Argun et al. [52] obtained a lower hydrogen yield ( $0.4 \mathrm{~mol} \mathrm{H}_{2} / \mathrm{mol}$ of glucose) with wheat powder $\left(2.5 \mathrm{~g} \mathrm{~L}^{-1}\right)$ in anaerobic batch reactors with a $\mathrm{pH}$ of 7.0 , at $30^{\circ} \mathrm{C}$, with heattreated acidogenic-anaerobic sludge rather than the one used in this study. Based on the best results reported, the authors applied higher concentrations of substrates than the present study. New tests need to be made with the isolates to be improved the hydrogen yields. In addition, it can be done by 
Table 3 - Comparison of hydrogen yields presented by different strains and substrates.

\begin{tabular}{|c|c|c|c|c|}
\hline Microorganisms & Substrate cultivation & Hydrogen yields & $\begin{array}{c}\mathrm{pH} \\
\mathrm{T}\left({ }^{\circ} \mathrm{C}\right)\end{array}$ & Reference \\
\hline E. cloacae $\mathrm{KBH} 3$ & Glucose $10 \mathrm{~g} \mathrm{~L}^{-1}$ & $1.8 \mathrm{~mol} \mathrm{H}_{2} / \mathrm{mol}$ glucose & $\begin{array}{l}7.0 \\
30^{\circ} \mathrm{C}\end{array}$ & [11] \\
\hline Enterobacter sp. & Glucose $19.8 \mathrm{~g} \mathrm{~L}^{-1}$ & $0.6 \mathrm{~mol} \mathrm{H}_{2} / \mathrm{mol}$ glucose & $40^{\circ} \mathrm{C}$ & [25] \\
\hline $\begin{array}{l}\text { Acidogenic consortia of } \\
\text { anaerobic bacteria }\end{array}$ & Wheat powder $2.5 \mathrm{~g} \mathrm{~L}^{-1}$ & $0.4 \mathrm{~mol} \mathrm{H}_{2} / \mathrm{mol}$ glucose & $\begin{array}{l}7.0 \\
30^{\circ} \mathrm{C}\end{array}$ & [52] \\
\hline E. aerogenes HU-101 & Glucose $10 \mathrm{~g} \mathrm{~L}^{-1}$ & $0.33 \mathrm{~mol} \mathrm{H}_{2} / \mathrm{mol}$ glucose & $37^{\circ} \mathrm{C}$ & [54] \\
\hline E. aerogenes IAM 1183 & $\begin{array}{l}\text { Xylose } 5 \mathrm{~g} \mathrm{~L}^{-1} \\
\text { Galactose } 10 \mathrm{~g} \mathrm{~L}^{-1}\end{array}$ & $\begin{array}{l}2.2 \mathrm{~mol} \mathrm{H}_{2} / \mathrm{mol} \text { xylose } \\
2.35 \mathrm{~mol} \mathrm{H}_{2} / \mathrm{mol} \text { galactose }\end{array}$ & $37^{\circ} \mathrm{C}$ & [55] \\
\hline E. aerogenes IAM1183 & Glucose 71.7 mM & $1.16 \mathrm{~mol} \mathrm{H}_{2} / \mathrm{mol}$ glucose & 6.9 & [56] \\
\hline E. aerogenes IAM1183-B ( $\Delta$ hycA) & & $1.20 \mathrm{~mol} \mathrm{H}_{2} / \mathrm{mol}$ glucose & $37^{\circ} \mathrm{C}$ & \\
\hline E. aerogenes IAM1183-O ( $($ hybO) & & $0.27 \mathrm{~mol} \mathrm{H}_{2} / \mathrm{mol}$ glucose & & \\
\hline E. aerogenes IAM1183-AO ( $\triangle \mathrm{hycA} / \Delta \mathrm{hybO})$ & & $1.36 \mathrm{~mol} \mathrm{H}_{2} / \mathrm{mol}$ glucose & & \\
\hline Enterobacter sp. & Glucose $2.0 \mathrm{~g} \mathrm{~L}^{-1}$ & $0.8 \mathrm{~mol} \mathrm{H}_{2} / \mathrm{mol}$ glucose & $\begin{array}{l}7.0 \\
37^{\circ} \mathrm{C}\end{array}$ & This study \\
\hline
\end{tabular}

keep screening for potential high rate and yield hydrogen producers and by using design of experiments to find out the best culture conditions.

\section{Conclusions}

- This study demonstrates the ability of Enterobacter sp. phylogenetic closely related strains, isolated from brewery wastewater, for hydrogen bioproduction at mesophilic condition. They were able to utilize different carbon sources, including sugars, starch and glycerol with high efficiencies on hydrogen generation. One of the them, growing in a glucose based medium $\left(2 \mathrm{~g} \mathrm{~L}^{-1}\right)$, showed a hydrogen yield of $0.8 \mathrm{~mol} \mathrm{H}_{2} \mathrm{~mol}^{-1}$ glucose.

- The isolation of new facultative anaerobic hydrogenproducing strains, such as Enterobacter sp., is of great interest, particularly at industrial scale, because it plays an important role in co-cultures (consisting of facultative and strict anaerobes) for dark fermentative hydrogen production. Furthermore, the wide substrate versatility, make them potential candidates for fermentative hydrogen production from diverse wastewaters, containing sugars and glycerol, which is desired from the environmental and economic point of view.

\section{Acknowledgments}

The authors gratefully acknowledge the financial support from Fundação de Amparo a Pesquisa do Estado de São Paulo (FAPESP - Proc 2012/01318-1), FUNDUNESP for the scholarship and CEMPEQC for supporting the chromatography analyses. CZL was supported by a scholarship from CNPq (Process nr. 202426/2014-9).

\section{R E F E R E N C E S}

[1] Das D, Veziroglu TN. Hydrogen production by biological process: survey of literature. Int J Hydrogen Energy 2001;26:13-28 (26):13-28.
[2] Turner JA. Sustainable hydrogen production. Science 2004;305:972-4.

[3] Fillaudeau L, Blanpain-Avet P, Daufin G. Water, wastewater and waste management in brewing industries. J Clean Prod 2006;14:463-71.

[4] Braeken L, Van Der Bruggen B, Vandecasteele C. Regeneration of brewery waste water using nanofiltration. Water Res 2004;38:3075-82.

[5] Kirin Kirin Beer University Report. Global Beer Production by Country in 2014. Available at: http://www.kirinholdings.co. jp/english/news/2015/0810_01.html.

[6] Simate GS, Cluett J, Iyuke SE, Musapatika ET, Ndlovu S, Walubita LF, et al. The treatment of brewery wastewater for reuse: state of the art. Desalination 2011;273:235-47.

[7] Perna V, Castelló E, Wenzel J, Lazaro CZ, Lima DMF, Borzacconi L, et al. Hydrogen production in an upflow anaerobic packed-bed reactor used to treat cheese whey. Int J Hydrogen Energy 2013;38:54-62.

[8] Lazaro CZ, Perna V, Eachebehere C, Varesche MBA. Sugarcane vinasse as substrate for fermentative hydrogen production: the effects of temperature and substrate concentration. Int J Hydrogen Energy 2014;39:6407-18.

[9] Lazaro CZ, Varesche MBA, Silva EL. Sequential fermentative and phototrophic system for hydrogen production: an approach for Brazilian alcohol distillery wastewater. Int J Hydrogen Energy 2015;40:9642-55.

[10] Maintinguer SI, Fernandes BS, Duarte ICS, Saavedra NK, Adorno MAT, Varesche MBA. Fermentative hydrogen production with xylose by Clostridium and Klebsiella species in anaerobic reactors. Int J Hydrogen Energy 2011;36:13508-17.

[11] Harun I, Jahim JM, Anuar N, Hassan O. Hydrogen production performance by Enterobacter cloacae KBH3 isolated from termite guts. Int J Hydrogen Energy 2012;37:15052-61.

[12] Sun L, Huang A, Gu W, Ma Y, Zhu D, Wang G. Hydrogen production by Enterobacter cloacae isolated from sugar refinery sludge. Int J Hydrogen Energy 2015;40:1402-7.

[13] Maintinguer SI, Sakamoto IK, Adorno MAT, Varesche MBA. Bacterial diversity from environmental sample applied to bio-hydrogen production. Int J Hydrogen Energy 2015;40:3180-90.

[14] Pan C-M, Fan Y-T, Zhao P, Hou H-W. Fermentative hydrogen production by the newly isolated Clostridium beijerinckii Fanp3. Int J Hydrogen Energy 2008;33:5383-91.

[15] Zhao X, Xing D, Fu N, Liu B, Ren N. Hydrogen production by the newly isolated Clostridium beijerinckii RZF-1108. Bioresour Technol 2011;102:8432-6.

[16] Wang X, Jin B, Mulcahy D. Impact of carbon and nitrogen sources on hydrogen production by a newly isolated 
Clostridium butyricum W5. Int J Hydrogen Energy 2014;33:4998-5005.

[17] O-Thong S, Prasertsan P, Karakashev D, Angelidaki I. Thermophilic fermentative hydrogen production by the newly isolated Thermoanaerobacterium thermosaccharolyticum PSU-2. Int J Hydrogen Energy 2008;33:1204-14.

[18] Roy S, Vishnuvardhan M, Das D. Improvement of hydrogen production by newly isolated Thermoanaerobacterium thermosaccharolyticum IIT BT-ST1. Int J Hydrogen Energy 2014;39:7541-52.

[19] Sheng T, Gao L, Zhao L, Liu W, Wang A. Direct hydrogen production from lignocellulose by the newly isolated Thermoanaerobacterium thermosaccharolyticum strain DD32. RSC Adv 2015;121:99781-8.

[20] Kumar N, Ghosh A, Das D. Redirection of biochemical pathways for the enhancement of $\mathrm{H}_{2}$ production by Enterobacter cloacae. Biotechnol Lett 2001;23:537-41.

[21] Shin J-H, Yoon JH, Ahn EK, Kim M-S, Sim SJ, Park TH. Fermentative hydrogen production by the newly isolated Enterobacter asburiae SNU-1. Int J Hydrogen Energy 2007;32:192-9.

[22] Kraemer JT, Bagley DM. Improving the yield from fermentative hydrogen production. Biotechnol Lett 2007;29:685-95.

[23] Jayasinghearachchi HS, Sarma PM, Singh S, Aginihotri A, Mandal AK, Lal B. Fermentative hydrogen production by two novel strains of Enterobacter aerogenes HGN-2 and HT 34 isolated from sea buried crude oil pipelines. Int J Hydrogen Energy 2009;34:7197-207.

[24] Rodrigues VC, Santana OK, Nespeca GM, de Oliveira JE, Maintinguer SI. Crude glycerol by transesterification process from used cooking oils: characterization and potentialities on hydrogen bioproduction. Int J Hydrogen Energy 2016;41:14641-51.

[25] Long CCA, Cui AJ, Liu AZ, Liu AY, Long BM, Hu Z. Statistical optimization of fermentative hydrogen production from xylose by newly isolated Enterobacter sp. Int J Hydrogen Energy 2010;35:6657-64.

[26] Karthic P, Joseph S, Arun N. Optimization of process variables for biohydrogen production from glucose by Enterobacter aerogenes. Open Access Sci Rep 2012;1:1-5.

[27] Ács N, Bagi Z, Rákhely G, Minárovics J, Nagy K, Kovács KL. Bioaugmentation of biogas production by a hydrogenproducing bacterium. Bioresour Technol 2015;186:286-93.

[28] Vatsala TM, Raj SM, Manimaran A. A pilot-scale study of biohydrogen production from distillery effluent using defined bacterial co-culture. Int J Hydrogen Energy 2008;33:5404-15.

[29] Bader J, Mast-Gerlach E, Popović MK, Bajpai R, Stahl U. Relevance of microbial coculture fermentations in biotechnology. J Appl Microbiol 2010;109:371-87.

[30] Maintinguer SI, Fernandes BS, Duarte IC, Saavedra NK, Adorno MAT, Varesche MBA. Fermentative hydrogen production by microbial consortium. Int J Hydrogen Energy 2008;33. 4309-1733.

[31] Dhole V, Kadam V. Advantages of the TOGA-Transformer Oil Gas Analyzer involving headspace-GC analysis and a DGA system. Application note 10348. Nasik, India: Thermo Fisher Scientific; 2012.

[32] Adorno MAT, Hirasawa JS, Varesche MBA. Development and validation of two methods to quantify volatile acids (C2-C6) by GC/FID: headspace (automatic and manual) and liquidliquid extraction (LLE). Am J Anal Chem 2014;5:406-14.

[33] Dubois M, Gilles KA, Hamilton JK, Rebers PA, Smith F. Colorimetric method for determination of sugars and related substances. Anal Chem 1956;28:350-6.

[34] Herbert D, Philipps OS, Strang RE. Carbohydrate analysis. Methods Enzym 1971;5B:265-77.
[35] APHA, AWWA, WEF. Standard methods for the examination of water and wastewater. 20th ed. Washington, D.C: American Public Health Association; 2005.

[36] Griffiths RI, Whiteley AS, O'Donnell AG. Rapid method for coextraction of DNA from natural environments for analysis of ribosomal DNA and rRNA-based microbial community composition. Appl Environ Microbiol 2000;66(12):5488-91.

[37] Lane DJ. In: Stackebandt E, editor. 16S/23S rRNA sequencing. Nucleic acid techniques in bacterial systematics; 1991. p. $115-75$.

[38] Macrogen Inc ${ }^{\circledR}$ http://www.macrogen.com.

[39] Ribosomal Database Project (RDP) http://rdp.cme.msu.edu/.

[40] National Center for Biotechnology Information sequence database http://www.ncbi.nlm.nih.gov/BLAST/.

[41] Santos SC, Rosa PRF Sakamoto IK, Varesche MBA, Silva EL. Continuous thermophilic hydrogen production and microbial community analysis from anaerobic digestion of diluted sugar cane stillage. Int J Hydrogen Energy 2014;39:9000-11.

[42] Lay JJ, Li YY, Noike T. Mathematical model for methane production from landfill bioreactor. J Environ Eng-ASCE 1998;124(8):730-6.

[43] Kawagoshi Y, Hino N, Fujimoto A, Nakao M, Fujita Y, Sugimura S, et al. Effect of seed sludge conditioning on hydrogen fermentation and $\mathrm{pH}$ effect on bacterial community relevant to hydrogen production. J Biosci Bioeng 2005;100(5):524-30.

[44] Baghchehsaraee B, Nakhla G, Karamanev D, Margaritis A. Fermentative hydrogen production by diverse microflora. Int J Hydrogen Energy 2010;35:5021-7.

[45] Kong HH, Oh J, Deming C, Conlan S, Grice E, Beatson MA, et al. Temporal shifts in the skin microbiome associated with disease flares and treatment in children with atopic dermatitis. Genome Res 2012;22:850-9.

[46] Zhang K, Ren N, Ai-Jie Wang. Enhanced biohydrogen production from corn stover hydrolyzate by pretreatment of two typical seed sludges. Int J Hydrogen Energy 2014:39:14653-62.

[47] Subudhi S, Nayak T, Ram Kumar N, Vijayananth P, Lal B. Impact of regulated $\mathrm{pH}$ on proto scale hydrogen production from xylose by an alkaline tolerant novel bacterial strain, Enterobacter cloacae DT-1. Int J Hydrogen Energy 2013;38:2728-37.

[48] Ren NQ, Chua H, Chan SY, Tsang YF, Wang YJ, Sin N. Assessing optimal fermentation type for bio-hydrogen production in continuous-flow acidogenic reactors. Bioresour Technol 2007;98:1774-80.

[49] Ren NQ, Guo WQ, Wang XJ, Xiang WS, Liu BF, Wang XZ, et al. Effects of different pretreatment methods on fermentation types and dominant bacteria for hydrogen production. Int J Hydrogen Energy 2008;33(16):4318-24.

[50] Hallenbeck PC. Fermentative hydrogen production: principles, progress, and prognosis. Int J Hydrogen Energy 2009;34(17):7379-89.

[51] Mandal B, Nath K, Das D. Improvement of biohydrogen production under decreased partial pressure of $\mathrm{H}_{2}$ by Enterobacter cloacae. Biotechnol Lett 2006;28(11):831-5.

[52] Argun H, Kargi F, Kapdan IK. Effects of the substrate and cell concentration on bio-hydrogen production from ground wheat by combined dark and photo-fermentation. Int J Hydrogen Energy 2009;34:6181-8.

[53] Fernández FJ, Villasen J, Or Infantes D. Kinetic and stoichiometric modeling of acidogenic fermentation of glucose and fructose. Biomass Bioenergy 2011;35:3877-83.

[54] Nakashimada Y, Rachman MA, Kakizono T, Nishio N. Hydrogen production of Enterobacter aerogenes altered by 
extracellular and intracellular redox states. Int J Hydrogen Energy 2002;27:1399-405.

[55] Ren Y, Wang J, Liu Z, Ren Y, Li G. Hydrogen production from the monomeric sugars hydrolyzed from hemicellulose by Enterobacter aerogenes. Renew Energy 2009;34:2774-9.
[56] Zhao H, Ma K, Lu Y, Zhang C, Wang L, Xing X-H. Cloning and knockout of formate hydrogen lyase and H2-uptake hydrogenase genes in Enterobacter aerogenes for enhanced hydrogen production. Int J Hydrogen Energy 2009;34:186-94. 